\title{
ANALYSIS OF REVIVAL PHENOMENON FOR STRONG-FIELD EXCITATION OF RYDBERG ATOM
}

\author{
R. Veilande, I. Bersons* \\ Institute of Atomic Physics and Spectroscopy, University of Latvia, \\ 19 Raina Blvd. Riga, LV-1586, LATVIA \\ "e-mail:bersons@latnet.lv
}

The autocorrelation function for a one-dimensional Rydberg atom irradiated by half-cycle pulse (HCP) is investigated. At weak field only the full revival is observed, at a medium field strength - a fractional revival, whereas at a strong field (when the continuous energy states are also populated) the revival phenomenon disappears. The contribution of the continuous energy states in the autocorrelation function decreases dramatically with time after the wave packet formation.

\section{INTRODUCTION}

Currently, interest is displayed in the study of a coherent superposition of quantum-mechanical states called wave packets. The evolution of these wave packets in time is the subject of many investigations (for reviews, see [1-3]). One of the most studied in the atomic physics is the Rydberg wave packets. Short laser pulses have made it possible to produce and monitor Rydberg wave packets [4-6]. In the last decade, Rydberg wave packets have also been generated with unipolar electric field pulses, termed half-cycle pulses (HCP's), whose duration is shorter than the Kepler period $t_{K}$ of the initial state $[7,8]$. The wave packet initially oscillates with the Kepler period, then collapses, and at time $t_{\text {rev }}$ revives into a shape close to the original. At the same time, additional temporal structures have been observed $[9,10]$ at times equal to the rational fractions of the revival time and have been interpreted [11] as a temporal formation of a number of "mini-packets". The revivals (fractional included) are sensitive to the number of states involved in the formation of a wave packet. In the present paper, we study the revivals of Rydberg wave packets created by HCP in a broad range of the momentum transferred to the electron, paying especial attention to the large momentum transfer when the ionization probability is significant. For simplicity, we consider a one-dimensional model of the Rydberg atom [12] which is an excellent approximation for the Rydberg atom in the extreme Stark state [13]. A very convenient tool for the investigation of the revival phenomenon is the autocorrelation function $[2,3]$ whose absolute square gives a projection of a moving packet into its initial state.

\section{FORMATION OF THE WAVE PACKET}

The wave packet formed as a superposition of one-dimensional energy eigenstates $\Psi_{n^{\prime}}(x)$ may be written as 


$$
\Psi(x, t)=\sum_{n^{\prime}} C_{n^{\prime}} \Psi_{n^{\prime}}(x) \exp \left(-i E_{n^{\prime}} t\right),
$$

where $E_{n^{\prime}}$ is the corresponding eigenvalue, with atomic units used.

The autocorrelation function is defined by the expression $[2,3,14]$ :

$$
A(t)=\langle\Psi(x, 0) \mid \Psi(x, t)\rangle=\sum_{n^{\prime}}\left|C_{n^{\prime}}\right|^{2} \exp \left(-i E_{n^{\prime}} t\right) .
$$

If the initial state with quantum number $n$ is irradiated by short HCP, the weighting factors $\left|C_{n^{\prime}}\right|^{2}$ estimated in the semi-classical approximation are [15]:

$$
\left|C_{n^{\prime}}\right|^{2}=\frac{2|q|^{3}}{\pi n^{3} n^{\prime 3}\left[\left(E_{n^{\prime}}-E_{n}-q^{2} / 2\right)^{2}-2 q^{2} E_{n}\right]^{2}},
$$

where $q=-\int F(t) \mathrm{d} t$ is the momentum transferred to the electron and $F(t)$ is the electric field of the HCP.

A comparison (see in [15]) with the quantum-mechanical calculations shows that Eq. (3) is very accurate in a broad region of the final energies $E_{n^{\prime}}$ and the momentum $q$. If the transferred momentum $q$ is large (the scaled momentum $p=q n \geq 1$ ), the ionization probability is significant, and the sum in Eq. (3) should also be extended to the positive final energies $E$. The weighting factor $\left|C_{n^{\prime}}\right|^{2}$ is given by the same Eq. (3) if the summation over $n^{\prime}$ is replaced by the integration over $n^{\prime 3} \mathrm{~d} E$. However, the integrand, especially at large $t$, oscillates very fast. To avoid these fast oscillations, we can replace the integration over the positive $E$ axis by the integration over the negative imaginary axis in the complex energy plane. The change of the integration direction leads to the additional term because the integrand has a pole at $p>1$. Therefore the autocorrelation function $A(t)$ can finally be presented as

$$
\begin{aligned}
& A(t)=\sum_{n^{\prime}=1}^{\infty} \frac{32|p|^{3} n^{2} \exp \left(i \pi n^{3} \tau / n^{\prime 2}\right)}{\pi n^{\prime 3}\left[\left(-n^{2} / n^{\prime 2}+1-p^{2}\right)^{2}+4 p^{2}\right]^{2}}- \\
& -\frac{16 i|p|^{3}}{\pi} \int_{0}^{\infty} \frac{\mathrm{d} y \exp (-\pi n \tau y)}{\left[\left(-i y+1-p^{2}\right)^{2}+4 p^{2}\right]^{2}}+
\end{aligned}
$$

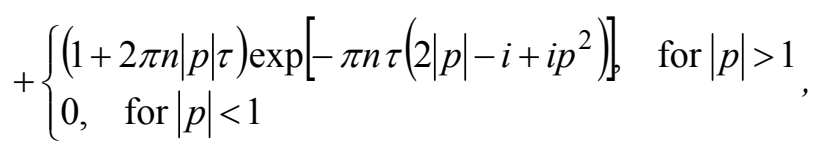

where the scaled time

$$
\tau=t / t_{K}=t /\left(2 \pi n^{3}\right)
$$

is introduced. At large $\tau$, the second term of Eq. (4) is given by 


$$
-\frac{16 i|p|^{3}}{\pi^{2} n \tau\left(1+p^{2}\right)^{4}} .
$$

\section{RESULTS AND DISCUSSION}

In Figs. 1-4 the absolute square of $A(t)$ is presented as a function of the scaled time $\tau=t / t_{K}$ at different values of the scaled momentum $p=q n$ transferred to the electron. The electron energy distribution $\mathrm{d} P / \mathrm{d} \varepsilon=\left|C_{n^{\prime}}\right|^{2} n^{\prime 3} /\left(2 n^{2}\right)$ is also shown in the insets. At $p=0.025$ (Fig. 1), only few states are populated and the pure revival phenomenon is observed in the time $t_{\text {rev }}=n / 3 \approx 13.3$. The fractional revival is absent. In Fig. 2 for $p=0.1$ and $n=40$ about ten states are populated, and the fractional revivals are clearly observed. When the momentum is $p=0.25$ (see Fig. 3), many states, even continuum energy states, are populated. The autocorrelation function is more chaotic and the fractional revivals are hardly observed. At $p=2$, the maximum of the electron energy distribution is in the continuum, the oscillations of the autocorrelation function are chaotic and the revival phenomenon disappears. From Fig. 4 it follows that the contribution of the states of continuous spectrum to the autocorrelation function is noticeable only during a small part of the first Kepler period, after which it is practically insignificant. This follows also from Eq. (4) and expression (6).

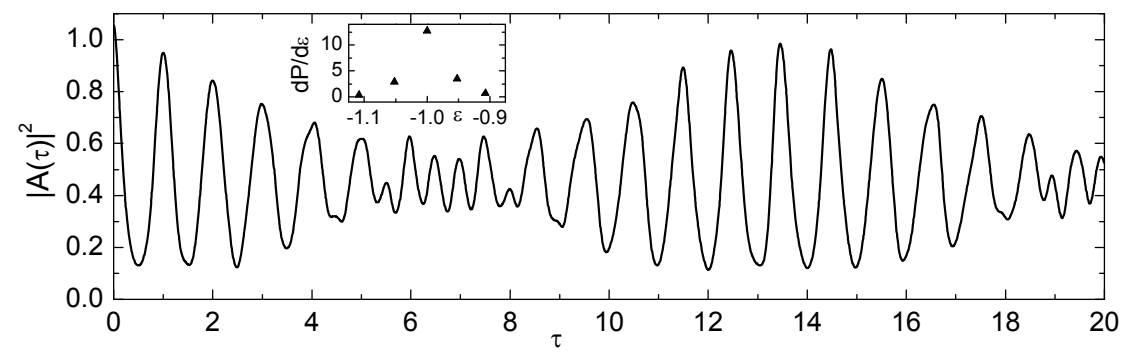

Fig. 1. The autocorrelation function $|A(\tau)|^{2}$ as a function of the scaled time $\tau=t /\left(2 \pi n^{3}\right)$ for a one-dimensional Rydberg atom with $n=40$ irradiated by HCP which transfers the momentum $p=q n=0.025$ to the electron. The revival time $t_{\text {rev }}=n / 3 \approx 13.3$. The inset shows the electron energy distribution $\mathrm{d} P / \mathrm{d} \varepsilon=\left|C_{n^{\prime}}\right|^{2} n^{\prime 3} /\left(2 n^{2}\right)$ as a function of the scaled energy $\varepsilon=E_{n^{\prime}} /\left|E_{n}\right|$.

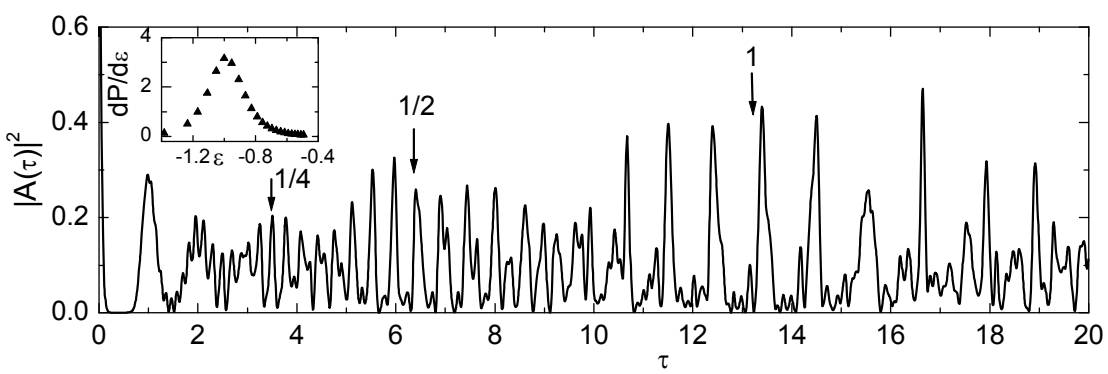

Fig. 2. The same as in Fig. 1 for $n=40$ and $p=q n=0.1$. Location of some fractional revivals are indicated by vertical arrows. 


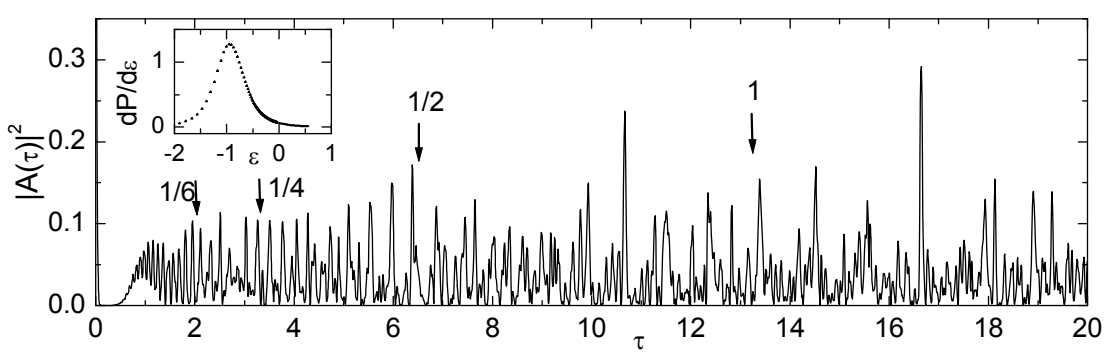

Fig. 3. The same as in Fig. 1 for $n=40$ and $p=q n=0.25$. Location of some fractional revivals are indicated by vertical arrows.

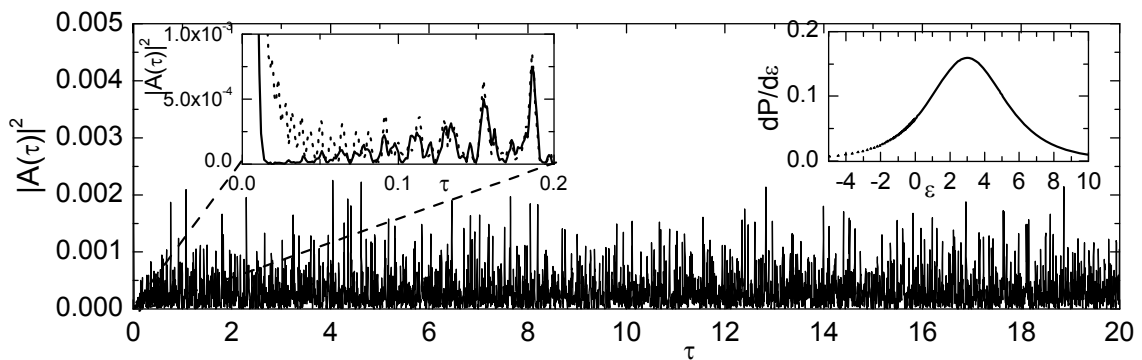

Fig. 4. The same as in Fig. 1 for $n=40$ and $p=q n=2$. The left inset shows the initial evolution of the created wave packets and the dotted line is the autocorrelation function $|A(\tau)|^{2}$ calculated without the continuous energy states. The right inset shows the electron energy distribution $\mathrm{d} P / \mathrm{d} \varepsilon$ as a function of the scaled energy $\varepsilon=E_{n^{\prime}} /\left|E_{n}\right|$.

\section{CONCLUSION}

In this paper we investigate the time dependence of the autocorrelation function for one-dimensional Rydberg atom irradiated by short HCP. If the HCP field is weak, only few states are populated, and the full revivals are well manifested themselves. At a stronger field, more states are involved in the formation of the wave packet, and the fractional revivals are observed. For strong fields, many Rydberg states are populated; the ionization is possible and, as a result, the revival phenomenon disappears and the autocorrelation function oscillates chaotically. It is interesting that even if the maximum of the electron energy distribution is in the continuum, the contribution of the positive energy states to the autocorrelation function decreases very fast after the wave packet creation. Physically this means that the electron in the continuous states leaves the atom very quickly.

\section{ACKNOWLEDGEMENT}

This work was supported by the Latvian Council of Science (Grant 09.1205) and Taiwan-Baltic project (1-23/172).

\section{REFERENCES}

1. Albert, G., \& Zoller, P. (1991). Phys. Rep. 199, 231.

2. Bluhm, R., Kostelecky, V.A., \& Porter, J.A. (1996). Am. J. Phys. 64, 944.

3. Robinett, R.W. (2004). Phys. Rep. 392 (1). 
4. Albert, G., Ritsch, H., \& Zoller, P. (1986). Phys. Rev. A, 34, 1058.

5. ten Wolde, A., Noordam, L.D., Lagendijk, A., \& van Linden, van den Heuvell, H.B. (1988). Phys. Rev. Lett., 61, 2099.

6. Yeazell, J.A., Mallalieu, M., Parker, J., \& Stroud (Jr), C.R. (1989). Phys. Rev. A, 40, 5040.

7. Reinhold, C.O., Burgdörfer, J., Frey, M.T., \& Dunning, F.B. (1996). Phys. Rev. A, 54, R33.

8. Bromage, J., \& Stroud (Jr), C.R. (1999). Phys. Rev. Lett., 83, 4963.

9. Parker, J., \& Stroud (Jr), C.R. (1986). Phys. Rev. Lett., 56, 716.

10. Meacher, D.R., Meyler, P.E., Hughes, I.G., \& Ewart, P. (1991). J. Phys. B, 24, L63.

11. Averbukh, I.Sh., \& Perelman, F. (1989). Phys. Lett. A, 139, 449.

12. Stokely, C.L., Dunning, F.B., Reinhold, C.O., \& Pattanayak, A.K. (2002). Phys. Rev. $A, 65,021405$.

13. Stokely, C.L., Lancaster, J.C., Dunning, F.B., Arbó, D.G., Reinhold, C.O. \& Burgdörfer, J. (2003). Phys. Rev. A, 67, 013403.

14. Veilande, R., \& Bersons, I. (2007). J. Phys. B, 40, 2111.

15. Bersons, I., \& Veilande, R. (2004). Phys. Rev. A, 69, 043408.

\section{ATJAUNOŠANĀS PARĀDĪBAS ANALĪZE RIDBERGA ATOMU IEROSMEI STIPROS LAUKOS}

R. Veilande, I. Bērsons

\section{Kopsavilkums}

Pētìta autokorelācijas funkcija viendimensionālam Ridberga atomam, kurš apstarots ar pusperioda impulsu (HCP). Kad ierosmes lauks ir vājš, tad novērojama tikai pilna atjaunošanās, bet kad lauka stiprums ir vidējs, tad parādās arī dalıeida atjaunošanās. Ja lauks ir spēcīgs, tad apdzīvoti ir arī nepārtrauktie enerǵijas stāvokḷi un atjaunošanās parādība izzūd. Nepārtraukto enerǵijas stāvokḷu ieguldījums autokorelācijas funkcijā strauji samazinās tūlìt pēc viḷnnu paketes radīšanas.

04.08.2009. 